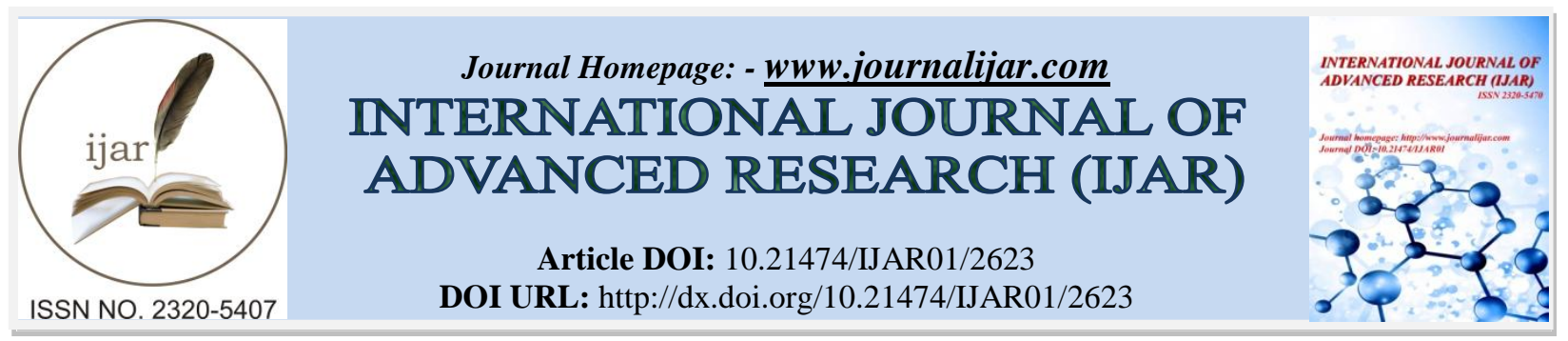

RESEARCH ARTICLE

\title{
SPECIALTY PREFERENCES AMONG MEDICAL STUDENTS IN RIYADH CITY.
}

\section{Dr. Khalid Al Qumaizi ${ }^{1}$, Abdullah Muqrin Al Muqrin' ${ }^{2}$, Rakan Mohammed Khawaji ${ }^{2}$, Abderrahman Mamoun Khalaf ${ }^{2}$, Abdullah Dhafer Algarni ${ }^{2}$ and Suliman Muhammed AI TERIQI2.}

1. Dean, College Of Medicine at Al-Imam Muhammad Ibn Saud Islamic University Consultant and Assistant Professor of Family Medicine.

2. Medical student, Al Imam Mohammad Ibn Saud Islamic University (IMSIU).

\section{Manuscript Info}

\section{Manuscript History}

Received: 30 October 2016

Final Accepted: 29 November 2016

Published: December 2016

Key words:-

Medical students, specialty preference, motivational factors.

\section{Abstract}

Background: Specialty selection is crucial for medical students in order to meet thedemands of Ministry of Health.This study profiles the specialty preferences of undergraduate medical students in Riyadh city and the factors influencing them.

Methods: We conducted a cross-sectional study on387 undergraduate medical students in three medical colleges (College of Medicine Al Imam Mohammad Ibn Saud Islamic University, College of Medicine King Saud University andCollege of MedicineAl Maarefa Colleges for Science \& Technology) in Riyadh city. The study was conducted during April and June 2014. Using avalidatedelectronicallyadministered structured questionnaire, wecollected data on demographic characteristics and specialty preferences of consenting students. Students also indicated the motivational factors underlying their preferences via responses to a Likert-type scale. We used Chisquare and t-tests to examine relationships between data types.

Results and Discussion: All participants were clear abouttheirspecialtypreference. Career specialty preferencesof the participants are as follows:90(23.3\%) participants chose surgery, 49 $(12.7 \%)$ selected internal medicine,38 (9.8\%) students preferred cardiology, 32 (8.3\%) each opted for neurology and ophthalmology,26 students selected pediatrics while $18(4.7 \%)$ each expressed interest in orthopedics and psychiatry, $16(4.1 \%)$ students desired to pursue family medicine, and 15 (3.9\%) students desired to pursue emergencymedicine. Radiology was the least preferred specialty, with only $10(2.6 \%)$ of the respondents indicating an interest. Gender did not appear to have a significant effect on career preferences of participants in our study. Students' GPA scores had a significant influence on their specialty choices $(\mathrm{p}<0.01)$. Personal interest, desire to serve the people, future job opportunities, prospects for high income and earlier rotations in the specialty ranked high as motivational factors forselection of career choices of the participants. Conclusions: Surgery, internal medicine, cardiology, neurology, and ophthalmology are the most preferred career specialties of medical students in Riyadh city. Students'choice of subject is mostly

Corresponding Author:- Dr. Khalid AlQumaizi. Assistant Professor of Family Medicine. 
influenced bypersonal interests, interest to serve, prospects for job and high income, and earlier learning experience.

Copy Right, IJAR, 2016,. All rights reserved.

\section{Introduction:-}

Mostmedical students after graduationdesire to pursue higher studies. However, they often find it difficult to choose a medical specialty, and their preferences often change considerably during their years of learning and clinical training [1].

Strong motivation is an essential requirement for the medical students to maintain patience and achieve professional success. Preference for a set ofspecialties isoften a strong motivationto pursue medicine. Many other factors, including demographic characteristics, medical school ethos and curriculum, as well as students' perceptions, attitudes and values, potentially influence the medical students' career plans regarding specialties[2-6].Their decision may also be influencedby suggestions from their peers, perception about competitionin the field, job opportunities, family expectations, marital status, and prospects for teaching and research in medical colleges, and the opportunity to practice overseas.

So far,there have been only a few systematic studies on the medical students' preferences for specialties and the motivational factors underlying them. Information from such studies can help the students make optimal choices and prepare for the expected career transitions. These studies can also yield important data regarding training and manpower requirement across medical specialties. No prior study has investigated these aspects of medical education in theRiyadh city;hence, the present study attempts to fill in this gap.

\section{Methods:-}

We performed a cross-sectional study on 387 medical students from three Medical Colleges (College of Medicine Al Imam Mohammad Ibn Saud Islamic University, College of Medicine King Saud University and College of Medicine Al Maarefa Colleges for Science \& Technology), during the monthsof April and June 2014.The students' participation was solicited via e-mail, and they were administered a validated structured questionnaire using online survey and a maintenance platform called SurveyMonkey. We calculated the sample size from 2507 undergraduate students by using survey system website with a confidence level of $95 \%$ and confidence interval of5. The questionnaire included items on demographic data and sought students' preferences from a list of 13 specialties, such asCardiology, Dermatology, Ear, Nose \& Throat (ENT), Emergency Medicine (ER), Family Medicine, Internal Medicine, Neurology, Ophthalmology, Orthopedics, Pediatrics, Psychiatry, Radiology, and Surgery. The respondents were instructed to write down their preference if it was not listed among the options. Students also indicated the degree to which 19 statements (developed after extensive literature review and interviews with medical students, interns, residents and educational experts) influenced their first preference. The students scored the responses on a 5-point Likert scale (ranging from 1, strongly disagree to 5, strongly agree).

\section{Data analysis:-}

We analyzed the data using IBM SPSS 22.0 (IBM, Chicago, IL, USA). Descriptive statistics and bar charts were used to represent data, and the Chi-square test was used to examine the relationship between categorical variables. Dimensions of Likert-type responses to statements were evaluated using the t-test. The values of $\mathrm{p}$ less than 0.05 were considered significant, and a confidence interval of $95 \%$ was calculated for each test.

\section{Results:-}

Demographic findings:-

The demographic and academic data of the participants are presented in Table 1. A total of 387 students (233 females and 154 males) were included in the study. A majority of the participants $(236 ; 61 \%)$ were aged between 20 to 22 years of age, and only 2 . 
Participants $(0.5 \%)$ were aged 25 years or older. The mean age of the participants in the study was 22 years. Of the respondents, 113 (29.2\%) were first-year students, followed by 84 (21.7\%) participantsin the third year.

Regarding the marital status, a majority of the participants $(347 ; 89.7 \%)$ were single and lived with their family while only $8(2.1 \%)$ participants were married. The assessment of the GPA scores revealed that $195(50.4 \%)$ participants had scored 4.5 or higher, followed by 115 (29.7\%) who had GPAscores between 4-4.5.Only 17 (4.4\%) participants had GPA scores less than 3.

Table 1:- Demographic and academic details of the participants

\begin{tabular}{|c|c|c|c|}
\hline Criterion & Category & Number & Percentage \\
\hline \multirow{3}{*}{ Gender } & Male & 233 & 60.2 \\
\hline \multirow{3}{*}{ Age in years } & Female & 154 & 39.8 \\
\cline { 2 - 4 } & Less than 20 & 55 & 14.2 \\
\cline { 2 - 4 } & 20 to 22 & 236 & 61.0 \\
\cline { 2 - 4 } & 22 to 25 & 94 & 24.3 \\
\cline { 2 - 4 } & More than 25 & 2 & 0.50 \\
\cline { 2 - 4 } & First & 113 & 29.2 \\
\cline { 2 - 4 } & Second & 72 & 18.6 \\
\cline { 2 - 4 } & Third & 60 & 21.7 \\
\cline { 2 - 4 } & Fourth & 58 & 15.5 \\
\hline \multirow{5}{*}{ Year of study } & Fifth & 8 & 15.0 \\
\cline { 2 - 4 } & Married & 22 & 2.10 \\
\cline { 2 - 4 } & Single, living alone & 347 & 5.70 \\
\cline { 2 - 4 } & Single, living with family & 10 & 89.7 \\
\cline { 2 - 4 } & Single, living with friends & 17 & 2.60 \\
\hline \multirow{3}{*}{ Student's } & Less than 3.00 & 60 & 4.40 \\
\cline { 2 - 4 } & $3.00-3.99$ & 115 & 15.5 \\
\cline { 2 - 4 } & $4.00-4.50$ & 195 & 29.7 \\
\cline { 2 - 4 } & More than 4.5 & & 50.4 \\
\hline
\end{tabular}

With respect to the specialty preferences of the participants (Table 2), it was found that Surgery was the most preferred specialty among the participants $(90 ; 23.3 \%)$, followed by Internal Medicinethat was opted by 49 (12.7\%) students. The least preferred specialty was Radiology as only 10 (2.6\%) participants opted for it.

Table 2:- .Specialty preferences of the study participants

\begin{tabular}{|c|c|c|}
\hline Specialty & Number of students preferring the specialty & Percentage \\
\hline Cardiology & 38 & 9.8 \\
\hline Dermatology & 31 & 8.0 \\
\hline Ear, Nose \& Throat (ENT) & 15 & 3.9 \\
\hline Emergency Medicine (ER) & 12 & 3.1 \\
\hline Family Medicine & 16 & 4.1 \\
\hline Internal Medicine & 49 & 12.7 \\
\hline Neurology & 32 & 8.3 \\
\hline Ophthalmology & 32 & 8.3 \\
\hline Orthopedics & 18 & 4.7 \\
\hline Pediatrics & 26 & 6.7 \\
\hline Psychiatry & 18 & 4.7 \\
\hline Radiology & 10 & 2.6 \\
\hline Surgery & 90 & 23.3 \\
\hline Total & $\mathbf{3 8 7}$ & $\mathbf{1 0 0 . 0}$ \\
\hline
\end{tabular}

Next, we investigated whether the students' preferences were influenced by their pre-medical academic performance using a non-parametric Chi-square test with cross-tabulation of the two attributes. The results of this analysis are presented in Table 3. We found a significant association between the student's earlier academic preference and their specialty preference (Chi-square, 66.84 and $\mathrm{p}<0.01$ ). 
Table 3:- Comparison of GPA scores of the respondents with the choice of their specialty.

\begin{tabular}{|c|c|c|c|c|c|}
\hline \multirow{2}{*}{ Preferred specialty } & \multicolumn{5}{|c|}{ GPA scores of the respondents } \\
\cline { 2 - 6 } & Less than 3 & $\begin{array}{c}3.00 \text { to } \\
3.99\end{array}$ & $\begin{array}{c}4.00 \text { to } \\
4.50\end{array}$ & More than 4.50 & Total \\
\hline Cardiology & 1 & 6 & 7 & 24 & 38 \\
\hline Dermatology & 1 & 2 & 10 & 18 & 31 \\
\hline ENT (Ear,Nose\& Throat) & 0 & 4 & 6 & 5 & 15 \\
\hline Emergency Medicine (ER) & 0 & 3 & 4 & 5 & 12 \\
\hline Family Medicine & 3 & 5 & 5 & 3 & 16 \\
\hline Internal Medicine & 0 & 4 & 11 & 34 & 49 \\
\hline Neurology & 1 & 3 & 7 & 21 & 32 \\
\hline Ophthalmology & 1 & 3 & 9 & 19 & 32 \\
\hline Orthopedic & 0 & 2 & 10 & 6 & 18 \\
\hline Pediatrics & 4 & 3 & 11 & 8 & 26 \\
\hline Psychiatry & 1 & 7 & 6 & 4 & 18 \\
\hline Radiology & 1 & 2 & 5 & 2 & 10 \\
\hline Surgery & 4 & 16 & 24 & 46 & 90 \\
\hline Total & $\mathbf{1 7}$ & $\mathbf{6 0}$ & $\mathbf{1 1 5}$ & $\mathbf{1 9 5}$ & $\mathbf{3 8 7}$ \\
\hline
\end{tabular}

We also investigated the gender influences on the choice of academic specialty by the participants. Table 4 depicts the findings from this evaluation. Theanalysis using Pearson Chi-Square test revealed no significant influence of gender on specialty preference among the participants (Chi-square, 19.1; $\mathrm{p}>0.05$ ).

Table 4:- Specialty preferences based on gender.

\begin{tabular}{|l|l|l|l|}
\hline \multirow{2}{*}{ Preferred specialty } & No. of respondents & \multirow{2}{*}{ Total number } \\
\cline { 2 - 4 } & Female & Male & \\
\hline Cardiology & 22 & 16 & 38 \\
\hline Dermatology & 24 & 7 & 31 \\
\hline ENT (Ear,Nose\& Throat) & 7 & 8 & 15 \\
\hline Emergency Medicine (ER) & 9 & 3 & 12 \\
\hline Family Medicine & 10 & 6 & 16 \\
\hline Internal Medicine & 26 & 23 & 49 \\
\hline Neurology & 20 & 12 & 32 \\
\hline Ophthalmology & 19 & 13 & 32 \\
\hline Orthopedic & 5 & 13 & 18 \\
\hline Pediatrics & 19 & 7 & 26 \\
\hline Psychiatry & 11 & 7 & 18 \\
\hline Radiology & 4 & 6 & 10 \\
\hline Surgery & 57 & 33 & 90 \\
\hline Total & $\mathbf{2 3 3}$ & $\mathbf{1 5 4}$ & $\mathbf{3 8 7}$ \\
\hline
\end{tabular}

Furthermore, we evaluated the students' responses to 19 categories of influencing factors, as the driving factor for their specialty preference. The responses to each criterion on a Likert scale from 1 to 5 were recorded, and the mean scores were calculated. A summary of the findings from this comparison is presented in Table 5. 
Table 5.Comparison of the influence of motivational factors in specialty preference

\begin{tabular}{|c|c|c|c|c|c|}
\hline \multirow{2}{*}{$\begin{array}{l}\text { Criterion for } \\
\text { specialty preference }\end{array}$} & \multicolumn{5}{|c|}{ Distribution of students' responses } \\
\hline & $\begin{array}{l}\text { Strongly } \\
\text { disagree }\end{array}$ & Disagree & Not sure & Agree & Strongly agree \\
\hline Friends' advice & $31 \%$ & $36 \%$ & $20 \%$ & $12 \%$ & $1 \%$ \\
\hline $\begin{array}{l}\text { Less competition in } \\
\text { the field }\end{array}$ & $35 \%$ & $30 \%$ & $21 \%$ & $11 \%$ & $3 \%$ \\
\hline $\begin{array}{ll}\begin{array}{l}\text { Future } \\
\text { opportunities }\end{array} & \text { job } \\
\end{array}$ & $8 \%$ & $15 \%$ & $18 \%$ & $42 \%$ & $16 \%$ \\
\hline $\begin{array}{l}\text { Family } \\
\text { expectations }\end{array}$ & $27 \%$ & $31 \%$ & $21 \%$ & $18 \%$ & $3 \%$ \\
\hline Marital status & $27 \%$ & $26 \%$ & $28 \%$ & $15 \%$ & $4 \%$ \\
\hline Personal interest & $1 \%$ & $2 \%$ & $2 \%$ & $20 \%$ & $75 \%$ \\
\hline Teachers'advice & $19 \%$ & $30 \%$ & $25 \%$ & $24 \%$ & $2 \%$ \\
\hline $\begin{array}{l}\text { Teaching } \\
\text { opportunities in } \\
\text { medical colleges }\end{array}$ & $15 \%$ & $30 \%$ & $29 \%$ & $19 \%$ & $6 \%$ \\
\hline $\begin{array}{l}\text { Shortage } \\
\text { specialists }\end{array}$ & $16 \%$ & $35 \%$ & $29 \%$ & $16 \%$ & $5 \%$ \\
\hline $\begin{array}{l}\text { Desire to practice } \\
\text { abroad }\end{array}$ & $9 \%$ & $24 \%$ & $24 \%$ & $29 \%$ & $15 \%$ \\
\hline $\begin{array}{l}\text { Research } \\
\text { opportunities in } \\
\text { medical colleges }\end{array}$ & $9 \%$ & $27 \%$ & $30 \%$ & $25 \%$ & $10 \%$ \\
\hline $\begin{array}{l}\text { Previous rotation in } \\
\text { the specialty }\end{array}$ & $6 \%$ & $17 \%$ & $28 \%$ & $33 \%$ & $16 \%$ \\
\hline Less work stress & $21 \%$ & $30 \%$ & $16 \%$ & $23 \%$ & $10 \%$ \\
\hline Role model & $11 \%$ & $22 \%$ & $29 \%$ & $29 \%$ & $10 \%$ \\
\hline Social acceptability & $21 \%$ & $29 \%$ & $19 \%$ & $24 \%$ & $7 \%$ \\
\hline $\begin{array}{l}\text { Desire to serve } \\
\text { people }\end{array}$ & $2 \%$ & $4 \%$ & $10 \%$ & $41 \%$ & $43 \%$ \\
\hline $\begin{array}{l}\text { Prestige } \\
\text { specialty }\end{array}$ & $17 \%$ & $26 \%$ & $27 \%$ & $25 \%$ & $\%$ \\
\hline $\begin{array}{l}\text { High-income } \\
\text { potential }\end{array}$ & $11 \%$ & $22 \%$ & $24 \%$ & $32 \%$ & $11 \%$ \\
\hline $\begin{array}{l}\text { Short period of } \\
\text { training }\end{array}$ & $25 \%$ & $35 \%$ & $22 \%$ & $14 \%$ & $3 \%$ \\
\hline
\end{tabular}

Table 6:- Scores for factors influencing specialty preference

\begin{tabular}{|c|c|c|c|c|c|}
\hline Factor influencing the student's specialty preference & Mean score & SD & Q1 & Median & Q3 \\
\hline Friends' advice & 2.2 & 1.0 & 1 & 2 & 3 \\
\hline Lesser competition in the field & 2.2 & 1.1 & 1 & 2 & 3 \\
\hline Future job opportunities & 3.4 & 1.2 & 3 & 4 & 4 \\
\hline Family expectations & 2.4 & 1.2 & 1 & 2 & 3 \\
\hline Marital status & 2.4 & 1.1 & 1 & 2 & 3 \\
\hline Personal interest & $\mathbf{4 . 7}$ & $\mathbf{0 . 7}$ & $\mathbf{4}$ & $\mathbf{5}$ & $\mathbf{5}$ \\
\hline Teachers' advice & 2.6 & 1.1 & 2 & 3 & 4 \\
\hline Seaching opportunities in medical college & 2.7 & 1.1 & 2 & 3 & 4 \\
\hline Shortage of specialists & 2.6 & 1.1 & 2 & 2 & 3 \\
\hline Desire to practice abroad & $\mathbf{3 . 2}$ & $\mathbf{1 . 2}$ & $\mathbf{2}$ & $\mathbf{3}$ & $\mathbf{4}$ \\
\hline Research opportunities in medical colleges & $\mathbf{3 . 0}$ & $\mathbf{1 . 1}$ & $\mathbf{2}$ & $\mathbf{3}$ & $\mathbf{4}$ \\
\hline Previous rotation in the specialty & $\mathbf{3 . 4}$ & $\mathbf{1 . 1}$ & $\mathbf{3}$ & $\mathbf{3}$ & $\mathbf{4}$ \\
\hline Low work stress & 2.7 & 1.3 & 2 & 2 & 4 \\
\hline Role models & $\mathbf{3 . 0}$ & $\mathbf{1 . 2}$ & $\mathbf{2}$ & $\mathbf{3}$ & $\mathbf{4}$ \\
\hline
\end{tabular}




\begin{tabular}{|c|c|c|c|c|c|}
\hline Social acceptability & 2.7 & 1.2 & 2 & 2 & 4 \\
\hline Desire to serve people & $\mathbf{4 . 2}$ & $\mathbf{0 . 9}$ & $\mathbf{4}$ & $\mathbf{4}$ & $\mathbf{5}$ \\
\hline Prestige of the specialty & 2.8 & 1.2 & 2 & 3 & 4 \\
\hline High income potential & $\mathbf{3 . 1}$ & $\mathbf{1 . 2}$ & $\mathbf{2}$ & $\mathbf{3}$ & $\mathbf{4}$ \\
\hline Short periods of training & 2.4 & 1.1 & 1 & 2 & 3 \\
\hline
\end{tabular}

As depicted inTable 6, the mean scores for the criteria except 'Personal interest', 'Desire to practice abroad', 'Research opportunities in medical college', 'Previous rotation in the specialty', 'Role models', 'Desire to serve people', and 'High income potential' were less than the neutral value of 3 .

We also recorded whether the students had a neutral response to the criteria mentioned. In cases where the response was not neutral, it wasevaluatedwhether they agreed or disagreed with the statement, using t-test. The results ofthis analysis are presented in Table 7.

Table 7:- Comparison of t-test results on the significance of individual motivational factors.

\begin{tabular}{|c|c|c|c|c|c|c|c|}
\hline \multirow[t]{2}{*}{ Criterion } & \multirow[t]{2}{*}{$\begin{array}{l}\text { Test } \\
\text { value }\end{array}$} & \multirow[t]{2}{*}{ t-score } & \multirow[t]{2}{*}{$\begin{array}{l}\text { Degrees of } \\
\text { freedom } \\
\text { (df) }\end{array}$} & \multirow[t]{2}{*}{$\begin{array}{l}\text { Significance } \\
\text { (2-tailed) }\end{array}$} & \multicolumn{2}{|c|}{$\begin{array}{l}95 \% \text { Confidence } \\
\text { Interval of the } \\
\text { Difference }\end{array}$} & \multirow[t]{2}{*}{ Remarks } \\
\hline & & & & & Lower & Upper & \\
\hline Friends' advice & 3 & -15.97 & 386 & 0.000 & -0.94 & -0.73 & $\begin{array}{l}\text { Significant at } 1 \% \\
\text { level; } t=-15.97 ; \\
\mathrm{p}<0.01\end{array}$ \\
\hline $\begin{array}{l}\text { Less competition } \\
\text { in the field }\end{array}$ & 3 & -15.03 & 386 & 0.000 & -0.95 & -0.73 & $\begin{array}{l}\text { Significant at } 1 \% \\
\text { level; } \mathrm{t}=-15.03 ; \\
\mathrm{p}<0.01\end{array}$ \\
\hline $\begin{array}{l}\text { Future } \\
\text { opportunities }\end{array}$ & 3 & 7.15 & 386 & 0.000 & 0.31 & 0.54 & $\begin{array}{l}\text { Significant at } 1 \% \\
\text { level; } t=7.15 ; \\
p<0.01\end{array}$ \\
\hline $\begin{array}{l}\text { Family } \\
\text { expectations }\end{array}$ & 3 & -10.14 & 386 & 0.000 & -0.71 & -0.73 & $\begin{array}{l}\text { Significant at } 1 \% \\
\text { level; } \mathrm{t}=-10.14 ; \\
\mathrm{p}<0.01\end{array}$ \\
\hline Marital status & 3 & -10.08 & 386 & 0.000 & -0.70 & -0.47 & $\begin{array}{l}\text { Significant at } 1 \% \\
\text { level; } \mathrm{t}=-10.08 ; \\
\mathrm{p}<0.01\end{array}$ \\
\hline Personal interest & 3 & 45.81 & 386 & 0.000 & 1.59 & 1.73 & $\begin{array}{l}\text { Significant at } 1 \% \\
\text { level; } t=45.81 ; \\
\mathrm{p}<0.01\end{array}$ \\
\hline Teachers' advice & 3 & -7.55 & 386 & 0.000 & -0.53 & -0.31 & $\begin{array}{l}\text { Significant at } 1 \% \\
\text { level; } \mathrm{t}=-7.55 ; \\
\mathrm{p}<0.01\end{array}$ \\
\hline $\begin{array}{l}\text { Teaching } \\
\text { opportunities in } \\
\text { medical colleges }\end{array}$ & 3 & -5.15 & 386 & 0.000 & -0.41 & -0.18 & $\begin{array}{l}\text { Significant at } 1 \% \\
\text { level; } t=-5.15 ; \\
\mathrm{p}<0.01\end{array}$ \\
\hline $\begin{array}{l}\text { Shortage } \\
\text { specialists }\end{array}$ & 3 & -7.56 & 386 & 0.000 & -0.52 & -0.31 & $\begin{array}{l}\text { Significant at } 1 \% \\
\text { level; } \mathrm{t}=-7.56 ; \\
\mathrm{p}<0.01\end{array}$ \\
\hline $\begin{array}{l}\text { Desire to practice } \\
\text { abroad }\end{array}$ & 3 & 2.68 & 386 & 0.008 & 0.04 & 0.29 & $\begin{array}{l}\text { Significant at } 1 \% \\
\text { level; } t=2.68 ; \\
\mathrm{p}<0.01\end{array}$ \\
\hline $\begin{array}{l}\text { Research } \\
\text { opportunities in } \\
\text { medical colleges }\end{array}$ & 3 & 0.05 & 386 & 0.964 & -0.11 & 0.11 & $\begin{array}{l}\text { Not significant at } \\
5 \% \text { level; } \mathrm{t}=0.5 ; \mathrm{p} \\
>0.05\end{array}$ \\
\hline $\begin{array}{l}\text { Previous rotation } \\
\text { in the specialty }\end{array}$ & 3 & 6.68 & 386 & 0.000 & 0.27 & 0.49 & $\begin{array}{l}\text { Significant at } 1 \% \\
\text { level; } t=6.68 ; \\
\mathrm{p}<0.01\end{array}$ \\
\hline Less work stress & 3 & -4.58 & 386 & 0.000 & -0.43 & -0.17 & Significant at $1 \%$ \\
\hline
\end{tabular}




\begin{tabular}{|l|l|l|l|l|l|l|l|}
\hline & & & & & & & $\begin{array}{l}\text { level; } \mathrm{t}=-4.58, \\
\mathrm{p}<0.01\end{array}$ \\
\hline Role model & 3 & 0.70 & 386 & 0.482 & -0.07 & 0.16 & $\begin{array}{l}\text { Not significant at } \\
5 \% \text { level; } \mathrm{t}=0.70 ; \\
\mathrm{p}>0.05 .\end{array}$ \\
\hline $\begin{array}{l}\text { Social } \\
\text { acceptability }\end{array}$ & 3 & -5.45 & 386 & 0.000 & -0.47 & -0.22 & $\begin{array}{l}\text { Significant at 1\% } \\
\text { level; t=-5.45; } \\
\mathrm{p}<0.01\end{array}$ \\
\hline $\begin{array}{l}\text { Desire to serve } \\
\text { people }\end{array}$ & 3 & 26.00 & 386 & 0.000 & 1.11 & 1.29 & $\begin{array}{l}\text { Significant at 1\% } \\
\text { level; t=26.0; } \\
\mathrm{p}<0.01\end{array}$ \\
\hline $\begin{array}{l}\text { Prestige } \\
\text { specialty }\end{array}$ & 3 & -3.45 & 386 & 0.001 & -0.32 & -0.09 & $\begin{array}{l}\text { Significant at } 1 \% \\
\text { level; t=-3.45; } \\
\mathrm{p}<0.01\end{array}$ \\
\hline $\begin{array}{l}\text { High income } \\
\text { potential }\end{array}$ & 3 & 1.50 & 386 & 0.135 & -0.03 & 0.21 & $\begin{array}{l}\text { Not significant at } \\
5 \% \text { level; } \mathrm{t}=1.50 ; \\
\mathrm{p}>0.05\end{array}$ \\
\hline $\begin{array}{l}\text { Short period of } \\
\text { training }\end{array}$ & 3 & -11.34 & 386 & 0.000 & -0.75 & -0.53 & $\begin{array}{l}\text { Significant at } 1 \% \\
\text { level; } \mathrm{t}=-11.34 ; \\
\mathrm{p}<0.01\end{array}$ \\
\hline
\end{tabular}

\section{Discussion:-}

The paper describes the results of a cross-sectional study on the preferenceof specialization of medical students in Riyadh city and the factors influencing them.

All students in our study wereclear about their preferences for their future specialty. This is in contrast to the findings of several studies thatreported students' indecision regarding the specialization for future practice [79].However, our findings are in agreement with the study by Gasiorowski, et al. [10].

Surgery, internal medicine, and cardiology were the three most preferred specialties according toour study, with $23.3 \%, 12.7 \%$ and $9.8 \%$ students, respectively, opting for them. This agrees with the findings of several earlier studies $[9,11,12]$. Only less than $5 \%$ of the respondents expressed a desire to pursue aspecializationin ENT, ER, family medicine, orthopedics, psychiatry, and radiology. Khader et al. [4] had earlier reported thatvery fewmedical students preferred tospecialize in orthopedics and dermatology.

Our findings revealed a significant influence of earlier academic performance on the choice of specialization taken up by a student(Chi-square, 66.84; $\mathrm{p}<0.01$ ). Surgery, internal medicine, and cardiology were the top three preferences among students with GPAs ranging from 4.00-4.50 while surgery, pediatrics, and family medicine were the most preferredchoices of those with GPAs less than 3 (Table 3). This seems to be in agreement with the findings of Khader, et al. [4]. Studies by Zolaly et al., Mehmood et al., Subba et al. and Alawaad et al. [11-14] suggested gender influences on the career choices of medical students. However, there were no major differences in the preference of specialization subject of the male and female students in our study. This is in consonance with the findings of Dorsey et al. [15] who investigated the career preferences of medical students in the U.S.

'Personal interests', 'desire to serve people', and 'future job opportunities' ranked high as the major influences on career preferences among our students, which is in congruence with the findings from similar studies in other countries $[10,16-20]$. This was followed by criteria like the 'potential for high income', 'earlier rotation in the specialty', and 'desire to practice abroad'.Alshahrani et al. [8], in a study on 379 medical students and interns in University of Dammam, Kingdom of Saudi Arabia, identified lifestyle, and not personal interests, had a greater impact on the students' choice of subject specialization.

Individual evaluation of responses scoring less than the neutral value of 3 (using t-test) revealed no significant influence by 'research opportunities in medical colleges', 'role models', and 'high-income potential' on the choice of specialty. Students' lack of interest in research and the lack of inspirational role models are points of concern raised by our study participants that warrant further attention. We observed that lifestyle was not a significant factor 
in the choice of a specialty by the medical students, which is in contrast with earlier reports of Newton et al. and Dorsey et al. [2, 15].

In our study, the prestige and social acceptability of the stream of specialization and shorter periods of training had a significant influence on the students' choices. This seems to be in agreement with the earlier reports by Dikici et al., Khader et al. and Mehmood et al. [4, 11, 21].

A significant number of our study participants belonged to the early years of medical education, with insufficient experience of the specialties, which might have influenced the overall results. We suggest that in future, studies shouldbe conducted with a larger number of final-year students, interns and residents to gain more accurate insights.

Overall, the findings from our study seem to agree with the reports from most other countriesthatsurgery, internal medicine, and cardiology arethe highly preferred specialties. The scarcity of inspirational role models in medical education and low levels of student interest in medical research also need further investigation.

\section{Competing interests:-}

The authors a that they have no competing interests.

\section{Authors' contributions}

Abdullah Muqrin Al Muqrin (AM) has formulated the general format of the study. In addition to that, he has also written the result section, the research questions and the statistical analysis.

Rakan Mohammed Khawaji (RK) has participated in the writing of the discussion part and was also part of the literature review team.

AbderrahmanMamounKhalaf(AK) has participated in the general design of the study along with writing of the methodology section.

Abdullah DhaferAlgarni (AG) participated in the writing of introduction and result section and general design of the study.

Suliman Mohammed Altreriqi (ST) has done extensive literature review and has written the discussion part.

\section{References:-}

1. Compton MT, Frank E, Elon L, Carrera J. Changes in U.S. medical students' specialty interests over the course of medical school. J Gen Intern Med. 2008; 23:1095-1100.

2. Newton DA, Grayson MS, Whitley TW. What predicts medical student career choice? J Gen Intern Med. 1998; 13:200-3.

3. Buddeberg-Fischer B, Klaghofer R, Abel T, Buddeberg C. Swiss residents' speciality choices — impact of gender, personality traits, career motivation and life goals. BMC Health Serv Res. 2006; 6:137.

4. Khader Y, Al-Zoubi D, Amarin Z, Alkafagei A, Khasawneh M, Burgan S et al. Factors affecting medical students in formulating their specialty preferences in Jordan. BMC Med Educ. 2008; 8:32.

5. Heiligers PJM. Gender differences in medical students' motives and career choice. BMC Med Educ. 2012; 12:82.

6. Kusurkar R, Kruitwagen C, ten Cate O, Croiset G. Effects of age, gender and educational background on strength of motivation for medical school. Adv Health SciEduc Theory Pract. 2010; 15:303-13.

7. Al-Fouzan R, Al-Ajlan S, Marwan Y, Al-Saleh M. Factors affecting future specialty choice among medical students in Kuwait. Med Educ Online.2012; 17:1-7.

8. Alshahrani M, Dhafery B, Al Mulhim M, Alkhadra F, Al Bagshi D, Bukhamsin N. Factors influencing Saudi medical students and interns' choice of future specialty: a self-administered questionnaire. Adv Med EducPract. 2014; 5:397-402.

9. Abdulghani HM, Al-Shaikh G, Alhujayri AK, Alohaideb NS, Alsaeed HA, Alshohayeb IS, et al. What determines the selection of undergraduate medical students to the specialty of their future careers? Med Teach 2013; 35 Suppl 1:S25-30.

10. Gasiorowski J, Rudowicz E, Safranow K. Motivation towards medical career choice and future career plans of Polish medical students. Adv Health SciEduc Theory Pract. 2015; 20:709-25. 
11. Mehmood SI, Kumar A, Al-Binali A, Borleffs JC. Specialty preferences: trends and perceptions among Saudi undergraduate medical students. Med Teach 2012; 34 Suppl 1:S51-60.

12. Alawad AA, Khan WS, Abdelrazig YM, Elzain YI, Khalil HO, Ahmed OB, et al. Factors considered by undergraduate medical students when selecting specialty of their future careers. Pan Afr Med J. 2015; 20:102.

13. Zolaly MA, Kasim K, Mahmoud MI. Medical career selection among newly graduated physicians in Madinah, KSA. Med Teach.2013; 35 Suppl 1:S63-7.

14. Subba SH, Binu VS, Kotian MS, Joseph N, Mahamood AB, Dixit N, et al. Future specialization interests among medical students in southern India. Natl Med J India. 2012; 25:226-9.

15. Dorsey ER, Jarjoura D, Rutecki GW. The influence of controllable lifestyle and sex on the specialty choices of graduating U.S. medical students, 1996-2003.Acad Med 2005; 80:791-6.

16. Draper C, Louw G. What is medicine and what is a doctor? Medical students' perceptions and expectations of their academic and professional career. Med Teach 2007; 29:e100-7.

17. Girasek E, Molnar R, Eke E, Szócska M. The medical career choice motivations-Results from a Hungarian study. Cent Eur J Med. 2011; 6:502-9.

18. Millan LR, Azevedo SR, Rossi E, De Marco OL, Millan MP, de Arruda PC. What is behind a student's choice for becoming a doctor? Clinics (Sao Paulo). 2005; 60:143-50.

19. Puljak L, Kraljevic JB, Latas VB, Sapunar D. Demographics and motives of medical school applicants in Croatia. Med Teach. 2007; 29:e227-34.

20. Todisco J, Hayes S, Farnill D. Career motivations of male and female medical students. Psychol Rep. 1995; 77:1199-202.

21. Dikici MF, Yaris F, Topsever P, Filiz TM, Gurel FS, Cubukcu M, et al. Factors Affecting Choice of Specialty Among First-year Medical Students of Four Universities in Different Regions of Turkey.Croat Med J. 2008; 49:415-20. 